\title{
EDITORIAL
}

\section{Relato de um Momento Importante: Reflexões dos alunos da disciplina Teoria da Contabilidade do Mestrado da USP, trinta anos depois.}

Como alunos do estimado Professor Sérgio de ludícibus na disciplina Teoria da Contabilidade no mestrado da USP, 30 anos atrás, gostaríamos de relembrar aquele importante momento de nossas vidas. É possível observar semelhanças e diferenças entre os dias de hoje e os daquele primeiro trimestre de 1978, quando ingressamos no Curso de Mestrado de Contabilidade da FEA para cursar a disciplina Teoria da Contabilidade. As aulas começavam em fevereiro e terminavam em maio.

O Mestrado e o Doutorado de Contabilidade na USP, que eram os únicos do Brasil, viviam seus primeiros momentos, porém todos nós alunos tínhamos uma grande convicção de que o curso seria uma base sólida para um futuro promissor. O Departamento de Contabilidade e Atuária e a própria FIPECAFI - que cabia em uma única sala - tinham uma dimensão bem diferente da que conhecemos atualmente. Apesar de pequeno, o corpo docente do programa já demonstrava o seu brilhantismo.

Naquela época, dava-se o início da vigência de uma nova lei, que trazia, em seu bojo, profundos efeitos contábeis e iria provocar grandes impactos nas organizações brasileiras (Lei 6404/76), de forma muito semelhante ao que está ocorrendo neste ano. A normatização contábil era muito tímida. A Comissão de Valores Mobiliários (CVM) iniciava suas atividades e o Instituto dos Auditores Independentes do Brasil (IBRACON), naquela época IAIB, estava em seu estágio inicial para emitir pronunciamentos. O Conselho Federal de Contabilidade (CFC) não emitia as Normas Brasileiras de Contabilidade e a legislação determinava a aplicação dos princípios contábeis geralmente aceitos, mas não havia uma clara determinação detalhando quais princípios.

Os principais textos abordando os princípios contábeis eram encontrados no livro "Contabilidade Introdutória" elaborado por um grupo de professores do Departamento de Contabilidade e Atuária da FEA, bem como no livro "Análise de Balanços" do Professor Sérgio de ludícibus, que se constituiu no ponto inicial para a concepção da Estrutura Básica Conceitual de Contabilidade aprovada pela CVM em 1986. Nas suas aulas, o Professor Sérgio apresentava esses temas através de uma conjugação da abordagem científica com uma linguagem poética permeada com muito bom humor. Em termos de Contabilidade Internacional, o FASB e o IASC completavam 5 anos e iniciavam o processo de normatização contábil. O FASB acabava de emitir o Statement 20 e toda a problemática da normatização contábil internacional era vista pelos alunos como algo muito distante da sua realidade.

A comunicação entre os alunos que residiam fora de São Paulo era feita através dos correios e em termos de tecnologia não havia micro computador, laptop, internet, celular, TV por assinatura e o telefone fixo funcionava de forma bastante instável. Naquela época, em termos econômicos, o Brasil era um país muito fechado, impactado por uma inflação elevada e com forte presença de empresas estatais, pois nem se sonhava com o processo de privatização que um dia viria a ocorrer. Já era marcante a presença de várias grandes empresas multinacionais em nosso país. Não existiam empresas brasileiras com ações listadas em bolsas no exterior, bem como não havia a atual movimentação de recursos de acionistas estrangeiros nas bolsas de valores brasileiras. A palavra Governança Corporativa não era conhecida e o Brasil vergava sob o peso de uma grande "dívida externa". Os bancos emprestavam recursos através de processos de empréstimos tradicionais e os modelos de operações financeiras estruturadas, os derivativos ou mesmo as operações de securitização, eram quase inexistentes.

Os impostos não eram tão pesados para os contribuintes como atualmente e a grande arrecadação do governo federal dava-se por meio do Imposto de Renda (não havia a Contribuição Social). Os impostos sobre as receitas não tinham a importância atual, porque as alíquotas eram bem menores que as atuais. O Governo oferecia maiores incentivos fiscais.

Ao ministrar a disciplina Teoria da Contabilidade, o Professor Sérgio de ludícibus utilizava um conjunto de apostilas que viriam constituir o seu famoso livro "Teoria da Contabilidade". O único livro internacional disponível sobre o tema era Accounting Theory de Hendriksen (sem o Van Breda). Esse, porém, era de difícil acesso uma vez que a biblioteca possuía apenas um único exemplar.

Fazer pesquisa contábil, naquele período, não era uma tarefa trivial. As únicas revistas nacionais de Contabilidade da época eram a Revista Brasileira de Contabilidade e a Revista Paulista de Contabilidade. Não havia, praticamente, dissertações e teses disponíveis, com exceção de poucas teses defendidas pelos próprios professores da USP. Ainda não existia o caderno Temática Contábil do Boletim IOB, que viria a ser coordenado pelo Professor Eliseu Martins e muito menos o Cadernos de Estudos que viria a se tornar a atual Revista de Contabilidade e Finanças da USP. 
A pesquisa, realizada através de revistas internacionais, apresentava uma grande dificuldade, pois era preciso passar horas em pé na biblioteca, folheando cada revista para encontrar o assunto desejado, para em seguida tirar cópias das foIhas necessárias. Imaginar, naquela época, que poderíamos um dia efetuar pesquisas, sentados em nossa própria sala, por meio de um computador ligado em tempo real a bases de dados internacionais, poderia passar apenas pela cabeça de Gene Roddenberry, roteirista da famosa série de televisão da época chamada "Star Trek" (Jornadas nas Estrelas).

Mesmo naquele ambiente "pré-moderno" e com as inúmeras dificuldades, o interesse dos alunos pela disciplina era enorme, graças ao grande fator motivacional existente despertado pela excelência com que eram ministradas as aulas do Professor Sérgio. Os debates eram profundos e os assuntos estudados, então, continuam a ser complexos até nos dias atuais, tais como: a essência econômica sobre a forma jurídica, critérios de mensuração de ativos, capitalização de gastos e o reconhecimento de receitas. O único tema que não era debatido em classe era o futebol, pois o Palmeiras era quase uma unanimidade.

Passados 30 anos, podemos constatar que os conceitos fundamentais que estudamos em Teoria de Contabilidade foram fundamentais como base de nossa atuação futura e são, ainda hoje, de grande relevância. O excelente programa apresentado na disciplina de 1978 continua plenamente válido em nossos dias. O domínio da base conceitual é algo permanente e não temporário, como é permanente a Contabilidade que se moderniza através dos tempos e se mantém como o grande arcabouço conceitual de mensuração econômica das entidades e fundamental instrumento de comunicação para seus usuários.

Esta turma de alunos, que ao longo desses 30 anos têm se empenhado em contribuir para a excelência do ensino e pesquisa da contabilidade no Brasil, reconhece a importância do legado conceitual que o Professor Sérgio proporcionou. Nosso eterno obrigado.

Turma de Alunos:

Anísio Candido Pereira Antonio de Jesus Mendes

Antonio J. Baccarin S. de Camargo Carlos Alberto Hideo Matsuda Carlos Matias Kolb Clóvis loshike Beppu José Carlos Marion José Hiro Nakamura Luiz Antonio Girnius Luiz Carlos Miranda Luiz Licco Netto Marcelo André Steuer Márcio Roberto Veneroso Mussolini Orrú Natan Szuster Reinaldo Guerreiro Waldomiro Carvas Walter Rodrigues Filho William Celso Silvestre yung Un Song 